\title{
FENOMENA EARNINGS MANAGEMENT SEBAGAI SEBUAH KECURANGAN
}

\author{
Yona Octiani Lestari \\ Jurusan Akuntansi Fakultas Ekonomi Universitas Islam Negeri (UIN) \\ Maulana Malik Ibrahim Malang \\ E-mail: yonaoctiani@yahoo.com
}

\begin{abstract}
This paper describes management earnings that is the way using by manager to influence systematic profit number and intend by chosening policy of accounting and accountancy procedure. Phenomenon of Earnings management like two sides currency. On one side (good), management earnings is ' legitimate' product, while on the other side (bad), earnings management is considered to be product from an ' immoral' and ' unethical' action There is three motivations in earnings management, that is capital market motivation that is accounting information by financial analysis and investor assisting price of stocks, contract motivation relates to long-term debt, that is manager boosting up net profit to lessen possibility of natural company of default technical (Healy : 1985) and motivation of regulation happened because government obliges financial statement in the form of accountancy number finally also generates the problem of earnings management conducted by managemen, because from manager exploits weakness of accountancy using estimation of accrual and election of accountancy method. Earnings management represent an action of immoral. Although earnings management is made to Standard Accountancy, but it is meaningless of earnings management represent smart action to legitamate of fraud.
\end{abstract}

Keyword: Earnings Management, Manager Motivations , Ethical Behaviour

Menurut Scott (1997) Seorang manajer akan memilih satu metoda atau kebijakan tertentu yang diperbolehkan GAAP dengan harapan dapat memaksimumkan utility mereka atau meningkatkan nilai oerusahaan. Cara yang digunakan manajer untuk mempengaruhi angka laba sistematis dan sengaja dengan cara memilih kebijakan akuntansi dan prosedur akuntansi tertentu bertujuan memaksimumkan utility manajer dan harga saham, perilaku diatas disebut sebagai earnings management (earning management).

Intan (2000) menjelaskan bahwa earnings management biasanya digunakan oleh manajer karena standar akuntansi memberikan keleluasaan untuk memilih kebijakan akuntansi atau metode akuntansi tertentu, tetapi harus tetap konsisten. Penerapan standar akuntansi tersebut ada yang bersifat mandatory (wajib ditaati) dan ada yang bersifat voluntary 
(manajemen leluasa memilih) sehingga manajer akan memilih satu metoda yang dianggap paling menguntungkan bagi manajer. Perilaku ini disebut opportunistic manajer

Pengetahuan tentang earnings management akan memungkinkan peningkatan manfaat informasi akuntansi, khususnya laporan laba rugi sebagai dasar pembuatan keputusan investor. Meskipun semua bagian dari laporan keuangan diperlukan, namun pada umumnya perhatian investor lebih tertuju pada laporan laba rugi, dengan anggapan bahwa stabilitas laba akan berdampak pada stabilitas deviden.

Dijelaskan oleh Healy (1985) bahwa terdapat beberapa cara yang digunakan oleh manajemen untuk melakukan earnings management, salah satu cara adalah dengan mengendalikan transaksi akrual. Transaksi akrual adalah transaksi yang tidak mempengaruhi aliran kas masuk maupun kas keluar. Misalnya pengakuan hutang, biaya atau piutang pendapatan. Transaksi akrual terdiri dari transaksi yang bersifat non-discretionary (bukan kebijakan atau mengubah metode akuntansi) yaitu transaksi yang dicatat dengan menggunakan satu prosedur apabila prosedur tersebut dipilih, maka manajemen diharapkan konsisten dalam menggunakan prosedur tersebut. Contoh dari transaksi akrual yang nondiscretionary adalah metoda depresiasi, penggunaan metoda akuntansi dalam perusahaan minyak antara full method dan successful effort, metoda penentuan harga pokok persediaan FIFO dan LIFO. Sedangkan transaksi akrual yang discretionary memberikan kebebasan kepada manajemen menentukan jumlah transaksi akrual secara fleksibel. Contoh yang termasuk transaksi ini adalah penentuan cadangan kerugian piutang yang nantinya akan menaikkan piutang dagang netto, menaikkan persediaan, menurunkan hutang dagang, dan hutang akrual (Scott, 1997)

Secara garis besar menurut Healy (1985) menyatakan bahwa penggunaan transaksi discretionary accruals, manajemen dapat mempengaruhi laba dengan mengendalikan jumlah transaksi akuntansi. Contoh transaksi discretionary accruals yaitu menaksir jumlah piutang tidak tertagih diturunkan dari tahun sebelumnya, sehingga jumlah piutang netto akan naik, dengan asumsi pendapatan tetap, maka laba tahun ini akan relative tinggi. Selain itu adanya perubahan taksiran umur ekonomis aktiva tetap atau amortisasi aktiva tidak berwujud. Proses yang dilakukan oleh manajemen tersebut dengan cara menggeser periode biaya atau pendapatan, sehingga manajemen dapat memperoleh keuntungan dibalik perubahan yang dilakukannya. 
Menggeser periode biaya atau pendapatan disebut manipulasi keputusan operasional. Contoh rekayasa periode biaya atau pendapatan antara lain; a) Mempercepat pengakuan pada periode sekarang atau menunda pengakuan biaya riset dan pengembangan sampai dengan periode akuntansi selanjutnya. b) Mempercepat atau menunda pengeluaran promosi sampai perioda akuntansi berikutnya, bekerjasama dengan vendor untuk mempercepat atau menunda pengiriman tagihan sampai perioda akuntansi berikutnya. c) Mempercepat atau menunda pengiriman produk ke pelanggan, menjual investasi sekuritas untuk memanipulasi tingkat laba, mengatur saat penjualan aktiva tetap yang sudah tidak dipakai dan lain-lain. Perusahaan mencatat persediaan menggunakan asumsi LIFO, juga dapat merekayasa peningkatan laba melalui pengaturan saldo persediaan.

\section{FENOMENA EARNINGS MANAGEMENT}

Fenomena earnings management seperti dua sisi mata uang. Pada satu sisi terang, earnings management adalah produk yang 'legitimate', sedangkan disisi lain (sisi gelap), earnings management dianggap sebagai produk dari suatu tindakan yang 'immoral' dan 'unethical'. Earnings management oleh sebagian kalangan dianggap sebagai 'proffesional judgement' atas laporan keuangan, tetapi dapat menyesatkan (mislead) pihak stakeholder dalam melakukan interpretasi terhadap performa ekonomi (economic perfomance) suatu perusahaan.

Dengan demikian dapat disimpulkan bahwa pihak manajemen telah dengan sengaja melakukan tindakan manipulasi atau tindakan lainnya yang dapat mempengaruhi laporan keuangan. Konsekuensinya akan lebih luas bila earnings management dilakukan oleh manajemen perusahaan go publik, pihak insvestor akan terlihat 'bodoh' bila mempercayai laporan keuangan tersebut. Biasanya hal ini dilakukan oleh pihak manajemen yang mempunyai keyakinan kuat bahwa pihak insvestor tidak mempunyai akses informasi ke dalam perusahaan, sehingga investor akan melihat laporan keuangan tersebut sebagai laporan yang true report.

Bila manajemen tidak mempengaruhi atau memanipulasi laporan keuangan, maka dapat disimpulkan bahwa earning quality telah bernilai positif. Data-data yang dilaporkan berarti dapat dipercaya dan dapat diandalkan. Tanpa campur tangan earnings management, berarti laporan keuangan telah benar-benar merefleksikan kondisi sebenarnya suatu perusahaan dan akan membantu pihak stakeholder dalam memprediksi performa ekonomi perusahaan tersebut dimasa datang. Sebagian kalangan - terutama kalangan akademisi, melihat bahwa 
earnings managemet terlihat "sangat menakutkan", karena aktivitas ini sangat berhubungan dengan moralitas dari manajemen.

Menurut Subiyantoro dan Triyuwono (2004:128) laporan keuangan sangat dibutuhkan oleh pemakai informasi karena dapat digunakan untuk memenuhi 4 (empat) hal, yaitu: 1) Pemilik perusahaan, 2) Keberlangsungan usaha, 3) Investasi masa depan, dan 4) Prestasi (manajemen). Laporan laba bagi kepentingan pemilik perusahaan berarti laporan laba berguna sebagai isi informasi laba dalam penyajian laporan keuangan dan setidaknya dapat menambah keuntungan secara pribadi pemilik perusahaan. Laporan laba menyangkut keberlangsungan usaha berarti hal ini didasarkan pada asumsi bahwa usaha dapat berlangsung bila ada ketersediaan kas sebagai modal usaha dalam perusahaan. Laporan laba berguna bagi investasi masa depan berarti informasi ini dapat digunakan sebagai bahan pertimbangan untuk keputusan masa depan menyangkut investasi usaha. Laporan laba berguna bagi peningkatan prestasi karyawan berarti laporan ini dapat mempengaruhi posisi atau kedudukan serta prestasi karyawan.

Informasi laba dalam praktiknya dapat mempengaruhi perilaku para pemakai informasi laporan keuangan, khususnya pihak investor dan kreditor. Apalagi dalam negara yang dalam perekonomiannya terdapat mekanisme pasar modal di dalamnya. Laba (earnings), kemampuan menghasilkan laba (earning power), dan kemampuan menciptakan kas (cash generating power) badan usaha dianggap sebagai indikator yang dapat mempengaruhi perilaku partisipan di pasar modal (Suwardjono, 2004:159). Informasi laba ini dibutuhkan oleh investor dan kreditor sebagai dasar keputusan terhadap tingkat pengembalian modal yang mereka investasikan.

Karena besarnya manfaat yang diberikan oleh laporan keuangan inilah, maka dibentuk sebuah aturan dalam proses pelaporan keuangan (financial reporting) yang disebut dengan Prinsip Akuntansi Berterima Umum (PABU) atau Generally Accepted Accounting Principles (GAAP). PABU adalah rerangka pedoman yang terdiri atas standar akuntansi dan sumbersumber lain yang didukung berlakunya praktik akuntansi secara resmi (yuridis), teoretis, dan praktis. Standar akuntansi berarti semua konsep, ketentuan, prosedur, metoda, dan teknik yang tersedia secara teoretis maupun praktis dalam proses pelaporan keuangan. Sedangkan sumbersumber lain bisa dalam bentuk praktik yang tidak diatur dalam standar akuntansi termasuk peraturan badan autoratif lain, kebiasaan dan konvensi yang membentuk praktik pelaporan keuangan yang sehat (sound practices) (Suwardjono, 2004:122). 
Tujuan dibentuknya Prinsip-Prinsip Akuntansi Berterima Umum (PABU) sebagai aturan dalam pelaporan keuangan adalah untuk menyeragamkan proses pelaporan keuangan (financial reporting) berikut hasilnya berupa laporan keuangan (financial statement) pada setiap entitas bisnis yang ada dalam sebuah negara, sehingga dapat mempermudah dalam proses pengauditan (auditing) atas kewajaran dalam pelaporannya. Tujuan lainnya adalah untuk mengukur tingkat keterbandingan (comparability) antara laporan keuangan entitas bisnis yang satu dengan yang lainnya, sehingga akan memperlihatkan keterbandingan (comparability) tingkat kinerja keuangannya.

Dengan diterapkannya Prinsip-Prinsip Akuntansi Berterima Umum (PABU) oleh setiap entitas bisnis, maka diharapkan laporan keuangan yang dihasilkan nantinya memiliki kualitas yang tinggi. Kualitas laporan keuangan yang tinggi dapat dilihat dari karakteristik-karakteristik kualitatif yang mendukungnya. Ikatan Akuntan Indonesia (2002) menyatakan bahwa terdapat empat karakteristik kualitatif pokok, yaitu dapat dipahami, relevan, keandalan, dan dapat diperbandingkan. Laporan keuangan dapat dipahami berarti laporan keuangan memiliki tingkat kemudahan yang tinggi untuk segera dapat dipahami oleh pemakai. Laporan keuangan relevan berarti informasi yang dihasilkan oleh laporan keuangan harus relevan untuk memenuhi kebutuhan pemakai dalam proses pengambilan keputusan. Laporan keuangan memiliki kualitas andal jika bebas dari pengertian yang menyesatkan, kesalahan material, dan dapat diandalkan pemakainya sebagai penyajian yang jujur dari yang seharusnya disajikan atau yang secara wajar diharapkan dapat disajikan. Laporan keuangan dapat diperbandingkan berarti laporan keuangan harus dapat diperbandingkan antar perode untuk mengidentifikasi kecenderungan (trend) posisi dari kinerja keuangan.

Dalam tataran normatif, Prinsip-Prinsip Akuntansi Berterima Umum (PABU) di atas memang dapat memberikan jaminan atas kualitas laporan keuangan yang diterbitkan oleh entitas bisnis. Tetapi dalam tataran praktis, Standar Akuntansi (sebagai salah satu aspek dari PABU) memiliki keterbatasan-keterbatasan yang dapat menjadikan laporan keuangan menjadi kurang andal (reliable). Keterbatasan-keterbatasan tersebut menurut Surifah (2000) di antaranya adalah: 1) Fleksibilitas penerapan metode akuntansi yang menyebabkan peluang bagi manajemen untuk melibatkan subyektifitas dalam menyusun metode akuntansi yang dipilih, dan 2) Penentuan waktu untuk pengeluaran-pengeluaran yang bersifat discretionary dapat dipergunakan oleh manajemen untuk mempengaruhi laba, yaitu dengan mempercepat atau 
menunda pengeluaran-pengeluaran tersebut dan menggesernya pada periode-periode yang lain. Fraser (dalam Surifah, 2000) juga menyebutkan keterbatasan laporan keuangan lainnya yaitu laporan keuangan berisi data masa lalu (historical data) sehingga memiliki keterbatasan informasi jika dikaitkan dengan likuiditas perusahaan pada masa yang akan datang.

Keterbatasan laporan keuangan di atas, pada praktiknya menimbulkan aktivitas manajemen laba (earnings management) oleh pihak manajemen perusahaan terhadap laporan keuangannya. Manajemen laba adalah tindakan yang ditujukan untuk memaksimumkan utilitas manajer dan cenderung untuk menguntungkan diri mereka (manajer) sendiri dengan cara mempengaruhi proses pelaporan keuangan. Sebagaimana yang dinyatakan oleh Setiawati dan Na'im (2000) bahwa manajemen laba adalah campur tangan manajemen dalam proses pelaporan keuangan eksternal dengan tujuan untuk menguntungkan diri sendiri. Berikut juga Scott (1997:369) yang menyatakan bahwa :

“.. manajemen laba adalah cara yang digunakan oleh manajer untuk mempengaruhi angka laba secara sistematis dan sengaja dengan cara memilih kebijakan akuntansi dan prosedur akuntansi tertentu yang bertujuan untuk memaksimumkan utilitas manajer dan atau nilai pasar dari perusahaan".

\section{MOTIVASI EARNINGS MANAGEMENT}

Motivasi untuk melakukan earnings management biasanya timbul akibat "pressure" baik dari dalam maupun dari luar perusahaan. Pressure dari dalam perusahaan biasanya berhubungan dengan perfoma keuangan yang tidak mencapai target yang telah ditentukan. Motivasi ini semakin kencang bila performa keuangan berhubungan dengan "reward" berupa insentive keuangan, seperti bonus atau untuk mendapatkan kompensasi yang maksimal.

Sedangkan motivasi dari luar, biasanya justru datang dari pihak top manajemen yang ingin menunjukkan bahwa berkat kepemimpinan mereka performa keuangan perusahaan telah menjadi lebih baik. Terutama bila perusahaan ini adalah perusahaan go public, maka pihak manajemen puncak (top management) ingin menunjukkan kepada para pemegang saham bahwa kepemimpinan mereka dapat diandalkan. Kecenderungannya akan lebih kuat, bila data aktual hanya berada dibawah sedikit dari target yang diinginkan. Maka earnings management berfungsi untuk "menyempurnakannya" menjadi laporan keuangan yang lebih baik Kemudian dalam kaitannya dengan pasar modal, earnings management juga dilakukan oleh pihak manajemen bila terdapat "gap" antara perfoma perusahaan dengan ekspektasi dari para analisis pasar modal. 
Manajemen biasanya secara agresif akan membuat laporan keuangan sesuai dengan "forecast" dari pihak analis pasar modal.

Motivasi lain adalah untuk membuat laporan keuangan lebih atraktif dan menarik dalam upaya mengajukan aplikasi pinjaman (loan application) atau melaksanakan IPO (Initial Public Offering). Bahkan dalam melakukan pengajuan aplikasi pinjaman, terdapat indikasi bahwa earnings management dilakukan justru untuk membuat laporan keuangan menjadi "sangat menyedihkan", dengan tujuan untuk mendapatkan belas kasihan suntikan dana dari pihak bank. Dalam Intan (2000) menunjukkan motivasi earnings management dikelompokkan menjadi 3 yaitu motivasi pasar modal, motivasi kontrak dan motivasi pemerintah.

\section{Motivasi Pasar Modal}

Informasi akuntansi oleh investor dan analis keuangan bermanfaat membantu menilai saham. Kesempatan ini digunaklan oleh manajer untuk memanipulasi laba dalam usaha mempengaruhi kinerja saham dalam jangka pendek. Penelitian earnings management pada pasar saham difokuskan atas perilaku unexpected accruals.

Menurut De Angelo (1988) menginvestigasi manajer dari 64 perusahaan terdaftar di NYSE (New York Stock Exchange). Manajer mengusulkan untuk membeli kembali saham yang beredar di masyarakat. Sampel diambil dari tahun 1973-1982. Hipotesis yang diajukan adalah manajer dapat membayar dengan harga lebih murah pada waktu membeli saham tersebut. Akan tetapi dia menemukan sedikit bukti earnings management oleh perusahaan yang melakukan pembelian kembali saham dengan menurunkan laba melalui discretionary accruals.

Perry dan Williams (1994) menguji unexpected accruals mengendalikan perubahan dalam pendapatan dan modal deprisiabel. Kecuali itu dilakukan dengan menambah sampel perusahaan sebanyak 175 perusahaan yang melakukan pengambilalihan saham pada thun 1981-1988. Hasil nya menunjukkan bahwa perusahaan yang manajernya ikut berpartisipasi dalam pengambilalihan saham terdapat bukti melakukan earnings management dengan cara menurunkan laba melalui discretionary accrual pada perioda sebelum dilakukan pengambilallihan. Hal tersebut dapat ditunjukkan dengan unexpected accruals negative (penurunan laba) sebelum management buyout.

Penelitian yang dilakukan oleh Teoh, Welch dan Wong (1998) adalah menaikkan laba selama perioda penerbitan saham. Perusahaan melaporkan positif (peningakatan laba) 
unexpected accruals sebelum penawaran saham. Pada saat IPO perusahaan berusaha menaikkan earnings dengan menggunakan akrual. Setelah tiga tahun IPO kinerja sahamnya mengalami penurunan $20 \%$ dari laporan keuangan saat IPO.

Bidang perbankan dan asuransi juga ada earnings management yang dilakukan oleh manajemen. Penelitian yang dilakukan oleh Baever, Eger, Ryan dan Wolfson (1989), Beatty, Chamberlain dan Magliolo (1995) melihat earnings management yang dilakukan oleh perbankan dan lembaga asuransi. Hasilnya menunjukkan adanya tingkat accrual positif. Penelitian ini dipertegas oleh penelitian Setiawati (1999) meneliti indikasi earnings management pada laporan keuangan yang dilaporkan lembaga perbankan pada Bank Indonesia karena disinyalir adanya asimetri informasi antara Bank Indonesia dan Bank-bank yang ditanganinya. Hasilnya bank yang mengalami penurunan kesehatan lebih banyak melakukan manipulsi laba.

\section{Motivasi Kontrak}

Motivasi kontrak berkaitan dengan utang jangka panjang, yaitu manajer menaikkan laba bersih untuk mengurangi kemungkinan perusahaan mengalami technical default. Healy (1985) menemukan banyak perencanaan bonus yang lebih rendah atau lebih tinggi dari batas minimal atau maksimal bonus yang harus dibayar. Jika manajer perusahaan mendapatkan laba yang diperoleh lebih rendah dari target laba maka manajer akan melakukan manipulasi laba dengan mentransfer laba yang diperoleh perioda sekarang ke perioda mendatang dengan harapan akan mendapatkan bonus.

Pada penelitian Sweeney (1994) bahwa perusahaan melakukan pengelolaan modal kerja dan ekuitas pemegang saham, dengan cara meningkatkan laba lima tahun kebelakang sehingga rasio debt to equity dan interest coverage relative pada posisi yang menguntungkan. Penelitian yang menguji debt equity hypothesis dengan mengevaluasi tingkat akrual 94 perusahaan yang melanggar perjanjian kredit. Penelitian dengan menggunakan model penelitian Jones (1991) untuk memproksikan normal akrual. Hasil penelitian membuktikan bahwa satu perioda sebelum pelanggaran perjanjian kredit, perusahaan merekayasa akrual. Hal ini dapat dilihat abnormal accrual perioda tersebut positif dan signifikan.

\section{Motivasi Regulasi.}

Pemerintah mewajibkan laporan keuangan dalam bentuk angka akuntansi akhirnya juga menimbulkan masalah earnings management yang dilakukan oleh manajemen. Hal ini timbul 
karena manajer memanfaatkan kelemahan akuntansi yang menggunakan estimasi akrual dan pemilihan metoda akuntansi. Jones (1991) pada penelitian yang dilakukan menghasilkan beberapa produsen yang melaporkan laba yang menurun dengan menggunakan discretionary accrual untuk mempengaruhi keputusan karena adanya regulasi import.

Pada tahun 1997 dipertegas oleh penelitian Hall dan Stammerjohan (1997) meneliti perusahaan minyak yang mengalami damage awards. Hal yang dilakukan perusahaan adalah meminimalkan pinalti, dengan cara pemilihan kebijakan akuntansi yang menurunkan laba. Alasan manajer melakukan hal tersebut karena dalam penentuan keputusan pengaadilan berdasar atas data akuntansi dengan mempertimbangkan kondisi keuangan. Perusahaan akan berusaha menurunkan laba perusahaan untuk mempengaruhi keputusan pengadilan.

Menurut Scott (2003:383) berbagai pola yang sering dilakukan manajer dalam earnings management adalah : Pertama, terjadinya taking a bath pada periode stress atau reorganisasi termasuk pengangkatan CEO baru. Bila perusahaan harus melaporkan laba yang tinggi, manajer dipaksa untuk melaporkan laba yang tinggi, konsekuensinya manajer akan menghapus aktiva dengan harapan laba yang akan datang dapat meningkat. Bentuk ini mengakui adanya biaya pada periode yang akan datang sebagai kerugian pada periode berjalan, ketika kondisi buruk yang tidak menguntungkan tidak dapat dihindari pada periode tersebut. Untuk itu manajemen harus menghapus beberapa aktiva dan membebankan perkiraan biaya yang akan datang pada saat ini serta melakukan clear the desk, sehingga laba yang dilaporkan di periode yang akan datang meningkat. Kedua, Income minimization, yang mana bentuk ini mirip dengan "taking a bath", tetapi lebih sedikit ekstrim, yakni dilakukan sebagai alasan politis pada periode laba yang tinggi dengan mempercepat penghapusan aktiva tetap dan aktiva tak berwujud dan mengakui pengeluaran-pengeluaran sebagai biaya. Pada saat earningsabilitas perusahaan sangat tinggi dengan maksud agar tidak mendapat perhatian secara politis, kebijakan yang diambil dapat berupa penghapusan atas barang modal dan aktiva tak berwujud, biaya iklan dan pengeluaran untuk penelitian dan pengembangan, hasil akuntansi untuk biaya eksplorasi.

Income maximization, dimana tindakan ini bertujuan untuk melaporkan net income yang tinggi untuk tujuan bonus yang lebih besar. Perencanaan bonus yang didasarkan pada 
data akuntansi mendorong manajer untuk memanipulasi data akuntansi tersebut guna menaikkan laba untuk meningkatkan pembayaran bonus tahunan. Jadi tindakan ini dilakukan pada saat laba menurun. Perusahaan yang melakukan pelanggaran perjanjian hutang mungkin akan memaksimalkan pendapatan.

Income smoothing, bentuk ini mungkin yang paling menarik. Hal ini dilakukan dengan meratakan laba yang dilaporkan untuk tujuan pelaporan eksternal, terutama bagi investor karena pada umumnya investor lebih menyukai laba yang relatif stabil. Teknik untuk merekayasa laba dapat dikelompokkan menjadi tiga kelompok (Setiawati dan Na'im, 2000). Pertama yaitu memanfaatkan peluang untuk membuat estimasi akuntansi, antara lain: estimasi tingkat piutang tak tertagih, estimasi kurun waktu depresiasi aktiva tetap atau amortisasi aktiva tak berwujud, estimasi biaya garansi. Kedua, yaitu mengubah metode akuntansi. Perubahan metode akuntansi yang digunakan untuk mencatat suatu transaksi, contoh: mengubah metode depresiasi aktiva tetap yaitu dari metode depresiasi angka tahun ke metode depresiasi garis lurus. Ketiga, yaitu menggeser periode biaya atau pendapatan, misalnya: mempercepat atau menunda pengeluaran untuk penelitian dan pengembangan sampai periode akuntansi berikutnya, mempercepat atau menunda pengeluaran promosi sampai periode akuntansi berikutnya, mempercepat atau menunda pengiriman produk ke pelanggan, menjual investasi sekuritas untuk memanipulasi tingkat laba, mengatur saat penjualan aktiva tetap yang sudahtidak dipakai.

Pendekatan lain yang digunakan dalam mengendalikan net income (Lontoh dan Lindrawati, 2004). Pertama, dengan mengendalikan transaksi-transaksi akrual, dimana transaksi akrual memiliki pengaruh terhadap pendapatan dan biaya namun tidak tampil pada arus kas. Contoh: amortisasi dan depresiasi adalah sepenuhnya dikuasai oleh perusahaan dalam hal menentukan masa manfaatnya sehingga perusahaan dapat mengatur besarnya pembebanan pada biaya sesuai keinginan manajemen dalam rangka mencapai hasil akhir pada net income yang diinginkan. Terdapat dua konsep akrual yaitu: discretionary accrual dan non discretionary accrual. Discretionary accrual adalah pengakuan akrual laba atau beban yang bebas tidak diatur dan merupakan pilihan kebijakan manajemen, sedangkan non discretionary accrual adalah pengakuan akrual laba yang wajar, yang tunduk pada suatu standar atau prinsip akuntansi yang berlaku umum. Kedua, dengan mengubah kebijakan akuntansi, manajemen juga dapat menentukan net income yang diinginkan, namun hasrat manajemen untuk 
melaksanakan hal ini tidak sekuat accrual items. Alasannya adalah manajemen harus menjelaskannya dalam disclosure pada laporan keuangan tahunan. Dan alasan ini adalah bahwa standar akuntansi tentang konsistensi mencegah terjadinya perubahan kebijakan akuntansi sesering mungkin. Contohnya adalah merubah metode pencatatan dari LIFO menjadi FIFO.

Earnings management merupakan fenomena yang sukar dihindari karena fenomena ini hanya dampak dari penggunaan dasar akrual dalam penyusunan laporan keuangan. Dasar akrual disepakati sebagai dasar penyusunan laporan keuangan karena dasar akrual memang lebih rasional dan adil dibandingkan dasar kas. Sebagai contoh, dengan dasar kas, pembelian aktiva tetap secara tunai senilai seratus juta rupiah mesti dibebankan sebagai biaya pada periode saat pembelian aktiva tersebut, meskipun aktiva tersebut akan bermanfaat bagi perusahaan selama 10 tahun. Jika laporan rugi laba disusun dengan dasar kas, maka besar kemungkinan dalam periode tersebut perusahaan dinyatakan mengalami rugi. Jadi pada dasarnya, basis akrual dipilih dengan tujuan untuk menjadikan laporan keuangan lebih informatif yaitu laporan keuangan yang benar-benar mencerminkan kondisi yang sebenarnya. Sayangnya, akrual yang ditujukan untuk menjadikan laporan yang sesuai fakta ini sedikit dapat digerakkan (tuned) sehingga dapat mengubah angka laba yang dihasilkan.

\section{ETHICAL BEHAVIOUR}

Earnings management merupakan suatu tindakan immoral. Walaupun earnings management dibuat berdasarkan Standar Akuntansi yang berlaku, tetapi tidak berarti earnings management merupakan tindakan cerdas untuk melegitimasi fraud.

Sampai saat ini belum ada metoda yang efektif untuk menghapus earnings management dari aktivitas akuntansi. Michael D. Acker, seorang guru besar dari Morquette University menyarankan perlunya edukasi yang membahas earnings management secara luas. Sehingga, akan banyak orang yang dapat mengindentifikasi teknik-teknik earnings management. Edukasi juga bisa dilakukan melalui media bisnis dan profesional yang mengajarkan pembacanya agar dapat mendeteksi earnings management secara praktis.

Beberapa literatur menunjukkan bahwa institusi yang diciptakan oleh investor dapat mampengaruhi, memonitor dan bahkan mendisiplinkan perilaku manajemen. Sedangkan dari internal perusahaan, Board of Director ( $B O D$ ) yang berasal dari luar perusahaan cenderung akan bertindak lebih independen, sehingga dapat memonitor dan mengontrol manajemen. 
Kemudian Literatur lain, menyarankan adanya regulasi yang dapat dengan segera mendekteksi adanya earnings management. Dalam regulasi tersebut, diatur tentang berapa jauh manajemen boleh melakukan "judgement" terhadap laporan keuangan melalui earnings management.

Perspektif etika terhadap suatu tindakan atau aktivitas bisnis sangat penting, karena etika bisnis dapat digunakan sebagai cara untuk menyelaraskan kepentingan strategis suatu bisnis atau perusahaan dengan tuntutan moralitas (Muhammad, 2004:60). Penyelarasan tersebut berarti merupakan sebuah upaya untuk merekonstruksi pemahaman tentang bisnis dan sekaligus mengimplementasikan bisnis sebagai media usaha atau perusahaan yang bersifat etis. Etika bisnis juga dapat melakukan perubahan kesadaran masyarakat tentang bisnis dengan memberikan suatu pemahaman atau cara pandang baru, yakni bahwa bisnis tidak terpisah dari etika (Muhammad, 2004:61).

Etika bisnis dalam kaitannya dengan ajaran agama, berarti sebuah pemikiran atau refleksi tentang moralitas yang membatasi kerangka acuannya kepada konsepsi sebuah organisasi dalam ekonomi dan bisnis yang didasarkan atas ajaran Islam. Etika bisnis mengatur tentang sesuatu yang baik atau buruk, wajar atau tidak wajar, atau diperbolehkan atau tidaknya perilaku manusia dalam aktivitas bisnis baik dalam lingkup individu maupun organisasi yang didasarkan atas ajaran Agama dalam hal ini adalah Islam

\section{KESIMPULAN}

Fenomena earnings management, motivasi manajer melakukan earnings management dan perilaku etik seorang manajer dalam dunia usaha adalah hal-hal yang sulit untuk dihindari. Terlebih apabila kepemilikan perusahaan terpisah dengan pengelola maka asimetri informasi juga turut mendukung terjadinya earnings management. Ada tiga motivasi melakukan earnings management yaitu motivasi pasar modal yaitu informasi akuntansi oleh investor dan analisis keuangan bermanfaat membantu menilai saham, motivasi kontrak berkaitan dengan utang jangka panjang, yaitu manajer menaikkan laba bersih untuk mengurangi kemungkinan perusahaan mengalami technical default (Healy :1985) dan motivasi regulasi terjadi karena pemerintah mewajibkan laporan keuangan dalam bentuk angka akuntansi akhirnya juga menimbulkan masalah earnings management yang dilakukan oleh manajemen. Hal ini timbul karena manajer memanfaatkan kelemahan akuntansi yang menggunakan estimasi akrual dan pemilihan metoda akuntansi. Earnings management merupakan suatu tindakan immoral. 
Walaupun earnings management dibuat berdasarkan Standar Akuntansi yang berlaku, tetapi tidak berarti earnings management merupakan tindakan cerdas untuk melegitimasi fraud. 


\section{DAFTAR PUSTAKA}

Aggarwal.R., R.Leal dan L.Hernandez. 1993. The After Market Performance of Initial Public Offering in Latin America, Financial Management, spring 1993: pp.42-53

Balvers.R, McDonal dan RE Miller, 1988, Underpricing of New Issues and the Choice of Auditor as a Signal of Investment Banker Reputation, The Accounting Review 63 (Oktober): 602-622

Bringham. Eugene F. dan Louis C. Gapenski. 1993. Intermediate Financial Management, Fourth Editions. New York: The Dryden Press.

Christy. MI. Hasan dan SD.Smith. 1996. A Note on Underwriter Competition and Initial Public Offering, Journal of Bussiness Finance And Accounting 23 May and June; 905-914

DeAngelo.L.E. 1988. Accounting Number as Valuations Substitutes: A Study of Management Buyouts of Public Stockholders. The Accounting Review, 59: 400-420

Firth. Michael dan Chee Keng Liau-Tan, 1998, Auditor Quality, Signaling and The Valuation of Initial Public Offering, Journal of Business Finance \& Accounting, 25 (1) \& (2), Jan/ March, pp. 145-165

Firth. Michael dan A. Smith. 1992. The Accuracy of Profits Forecasts in Initial Public Offerings Prospektus, Accounting and Business Research, Vol. 22 No. 87, pp. 239-247

Gumanti, A. Tatang. Earning Management dalam Penawaran Saham Perdana Di BEJ, Makalah Simposium Nasional Akuntansi III, 2000

Healy, P.M dan James M. Wahlen. 1998. A Review of The Earnings Management Literature and Implications for Standard Setting, Journal Accounting Research

Healy, P.M. 1985. The Effect of Bonus Schemes on Accounting Decisions, Journal of Accounting and Economics, Vol. 10, pp. 85-107

Husnan, Suad (1996). Penjualan Saham BUMN: Apakah Terjadi Distribusi Kemakmuran ?, Kelola No 13 Mei,p.62-74

Jogiyanto. 1998. Teori Portofolio dan Analisis Investasi, edisi pertama, BPFE, Yogyakarta

Jones, Charles P. 1996. Invesment : Analysis and Management, New York, John Wiley and Sons Inc

Jones, J. 1991. Earning Management During Import Relief Investigations. Journal of Accounting Research Vol. 29 No. 2 Autumn, pp. 193-228 
Juanda, Ahmad. Earning Management dan Kinerja Saham Perusahaan Yang Melakukan IPO, Jurnal Ekonomi Universitas Muhammadiyah Malang, volume 12 No 18, Januari-Juni 2002,pp. 297-314

Kim, Jeong Bong, I. Krinsky dan J. Lee. 1993. Motives for Going Public and Underpricing: New Finding from Korea. Journal of Business Finance and Accounting, 20 (2) January, pp. 195-211

Machfoed, Mahmud. Juli 1998. Faktor-faktor yang Mempengaruhi Praktik Perataan Laba pada Perusahaan yang Terdaftar di Bursa Efek Indonesia, Jurnal Riset Akuntansi Indonesia, Vol. 1, No. 2, Hal. 174-191

Naim. A dan Hartono, 1996, The Effect of Untitrust Investigations on Management of Earning: A Test on Political Cost Hyothesis. Kelola: Gadjah Mada University Business Review No.13/V, pp. 126-141s

Rao, Gita R. 1993. The Relation Between Stock Return and Earning: A Study of Newly-Public Firm. Working Paper. Kidder Peabody and Co. New York. Dalam Teoh, Siew Hong, Ivo Welch dan T.J Wong, 1998a, Earning Management and The Long Run Market Performance of Initial Public Offering. Journal of Finance, Vol. LIII. No. 6 Desember, pp. 1935-1974

Scott, William R. 1997. Financial Accounting Theory, Prentice-Hall International, Inc

Setiawati, Lilis. 1999. Penilaian Kesehatan Bank oleh Indonesia dan Manajemen Laba dalam Perbankan, Thesis S2 UGM, tidak dipublikasikan

Sweeney, A.P. 1994. Debt-Covenant Violations and Managers Accounting Response, Journal of Accounting ang Economics (May): pp 281-308

Sutanto, I Intan (2000). Indikasi Manajemen Laba Menjelang IPO Oleh PerusahaanPerusahaan Yang Terdaftar di Bursa Efek Indonesia, Thesis S2 UGM, tidak dipublikasikan

Teoh, Siew Hong, Ivo. Welch dan T.J. Wong. 1998a, Earning Management and The Long Run Market Performance Of Initial Public Offering, Journal of Finance, Vol. LIII No. 6. Desember, pp. 1935-1974

Titman dan Trueman. 1986. An Explanation for Accounting Income Smoothing, Journal of Accounting Research, Suplement, pp. 127-143 